\title{
Sedimentary indicators of a deep sea environment, in the sandstones of rocky forms, from the Ciężkowice-Rożnów Landscape Park (Outer Carpathians, Poland)
}

\author{
Świadectwa środowisk głębokomorskich w piaskowcach skałek \\ Ciężkowicko-Rożnowskiego Parku Krajobrazowego (Karpaty Zewnętrzne)
}

\author{
Renata Stadnik, Anna Waśkowska \\ AGH University of Science and Technology, Faculty of Geology, Geophysics and Environmental Protection, \\ al. Mickiewicza 30, 30-059 Krakow, \\ e-mail:stadnik@agh.edu.pl,waskowsk@agh.edu.pl
}
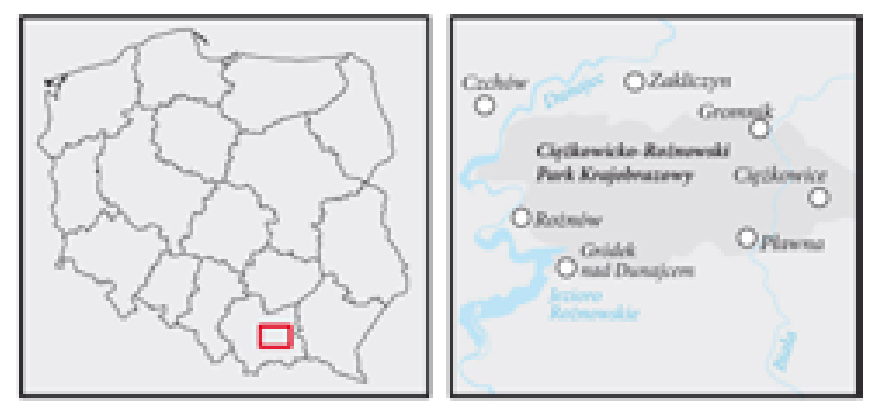

Abstract: The rocky forms of the Ciężkowice-Rożnów Landscape Park form the remains of the solid cover of the Cięzkowice Sandstone. Deposits in rocky forms represent different types of facies. Numerous and genetically diverse sedimentary structures in the sandstones are typical for a deep-sea flysch environment. Analysis of these well preserved features makes it possible to interpret the paleoenvironment of their sedimentation in the Eocene. These features have also become unusually valuable, in terms of both research methodology, known as sedimentological facies analysis, as well as in popularising geological knowledge.

Key words: geotouristic, Outer Carpathians, Ciężkowice Sandstone, sandstone rocky forms, sedimentary structures

Treść: Skałki Ciężkowicko-Rożnowskiego Parku Krajobrazowego sq obiektami, które pozostaty po zwartym kompleksie piaskowca ciężkowickiego. Na ich powierzchniach czytelne są liczne i zróżnicowane genetycznie struktury sedymentacyjne oraz litofacje, które sa typowe dla fliszowych środowisk glębokomorskich. Stopień wyrazistości tych struktur na powierzchniach skałekjest wysoki, dlatego stanowia one nie tylko obiekty cenne dla interpretacji paleośrodowisk, ale również cenne dla popularyzacji wiedzy geologicznej. Slowa kluczowe: geoturystyka, Karpaty Zewnętrzne, piaskowiec ciężkowicki, piaskowcowe formy skatkowe, struktury sedymentacyjne

\section{Introduction}

The Ciężkowice-Rożnów Landscape Park is a popular tourist destination in Poland. It is noted for its peace and quiet, natural beauty and hilly landscape. This area is unique in Poland, as large numbers of a wide variety of rocky forms are exposed within a small area (Fig. 1). The area's geology itself is a tourist attraction, and many of the hiking trails pass close to these exposed rocky forms. The most spectacular of these are under legal protection. The rocky forms are diverse in terms of size and shape (Fig. 2, 3,4). Many of them have individual names connected with their morphological resemblance to things or creatures. These geological forms have long attracted human interest and have been studied by geologists for more than 130 years (eg. Walter, Dunikowski, 1883; Grzybowski, 1921; Koszarski, 1956; Alexandrowicz, 1970; Leszczyński, 1981, 1989; Cieszkowski et al., 1991; Leszczyński, Radomski, 1994). Whilst they are legally protected, due to their geological value and rarity, they also belong to the most popular geotouristic sites in the Carpathians (e.g. Motyka, 1927; Tomek, 1949; Alexandrowicz, Poprawa, 2000; Alexandrowicz, 2006, 2008; Gruszka, 2009; Doktor et al., 2010; Bartuś et al., 2012 and papers cited therein).

The rocky forms represent separate fragments of a disintegrated rock cover built of flysch deposits. They are the most resistant remains of a solid rock complex (e.g. Klimaszewski, 1947; Alexandrowicz 1970, 1977, 2008). On the one hand, their presence provides evidence of the scale of advanced erosive processes, while, on the other, they provide insight into deep-sea environments from tens of millions of years ago. Analysis of the sandy deposits and in particular of the sedimentary structures, was the basis for determining the genesis of these rocks (Koszarski, 1956; Leszczyński, 1981, 1989). The objective of this paper was to collect and present the most popular sedimentary structures and lithofacies, occurring in rocky forms of the Ciężkowice-Rożnów Landscape Park, considered within the context of the paleoenvironment of their sedimentation.

\section{Study area}

The Ciężkowice-Rożnów Landscape Park is situated in Poland's Małopolska province. Since 1995, more than 17 thousand hectares, in the southwestern part of the Rożnów Foothills and the southern part of the Ciężkowice Foothills (Kondracki, 2009), between the Dunajec and Biała river valleys, have been placed under legal protection (Fig. 1). 


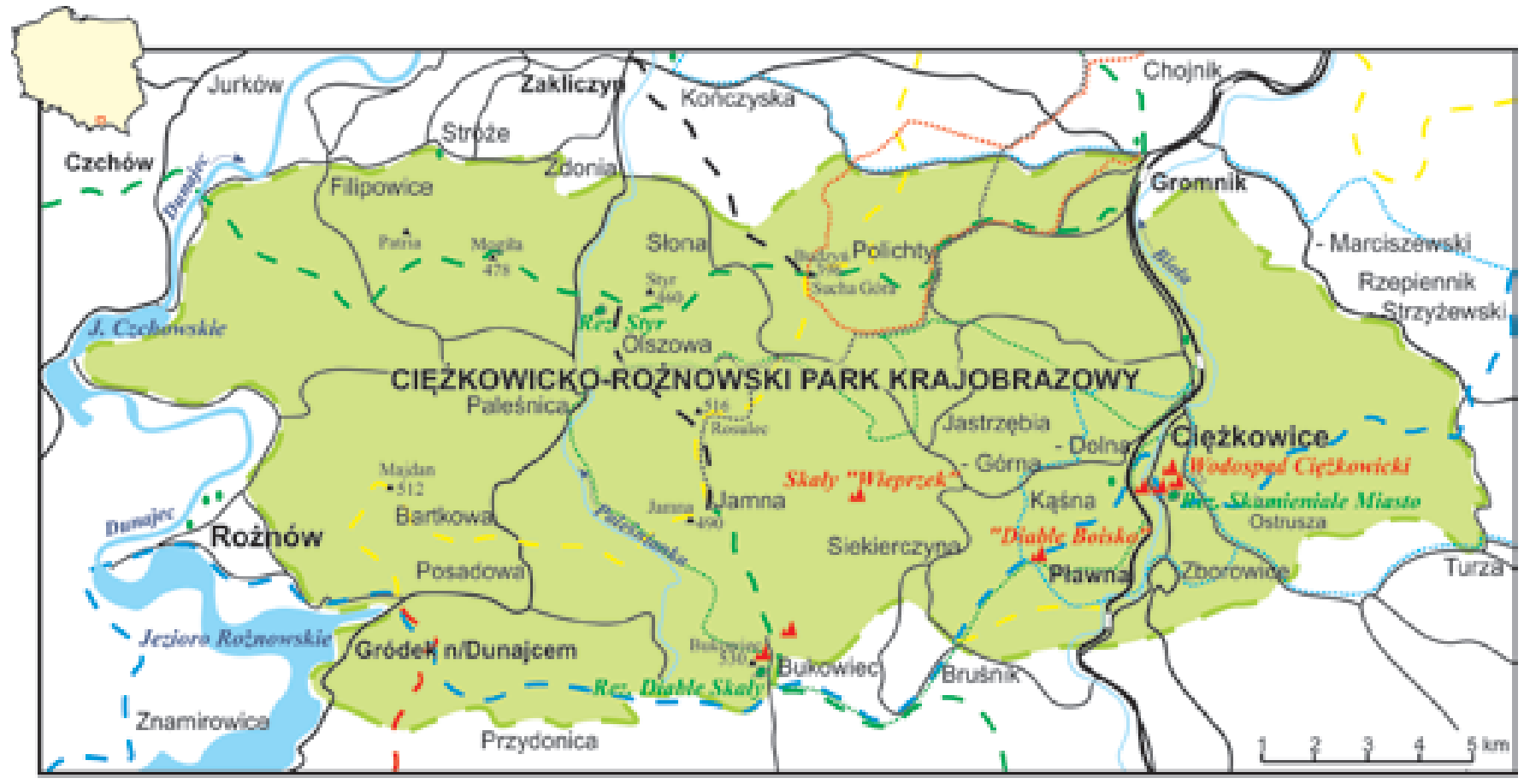

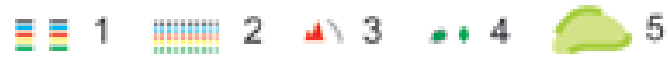

Fig. 1. Distribution of protected rocky forms within the Ciężkowice-Rożnów Landscape Park: 1 - hiking trails, 2 - bike trails, 3 - protected rocky forms and quarry, 4 - other protected objects, 5 - area of the Ciężkowice-Rożnów Landscape Park • Rozmieszczenie chronionych obiektów skałkowych na terenie Ciężkowicko-Rożnowskiego Parku Krajobrazowego: 1 - szlaki piesze, 2 - szlaki rowerowe, 3 - formy skałkowe i kamieniołomy podlegające ochronie prawnej, 4 - inne chronione obiekty, 5 - obszar Ciężkowicko-Rożnowskiego Parku Krajobrazowego

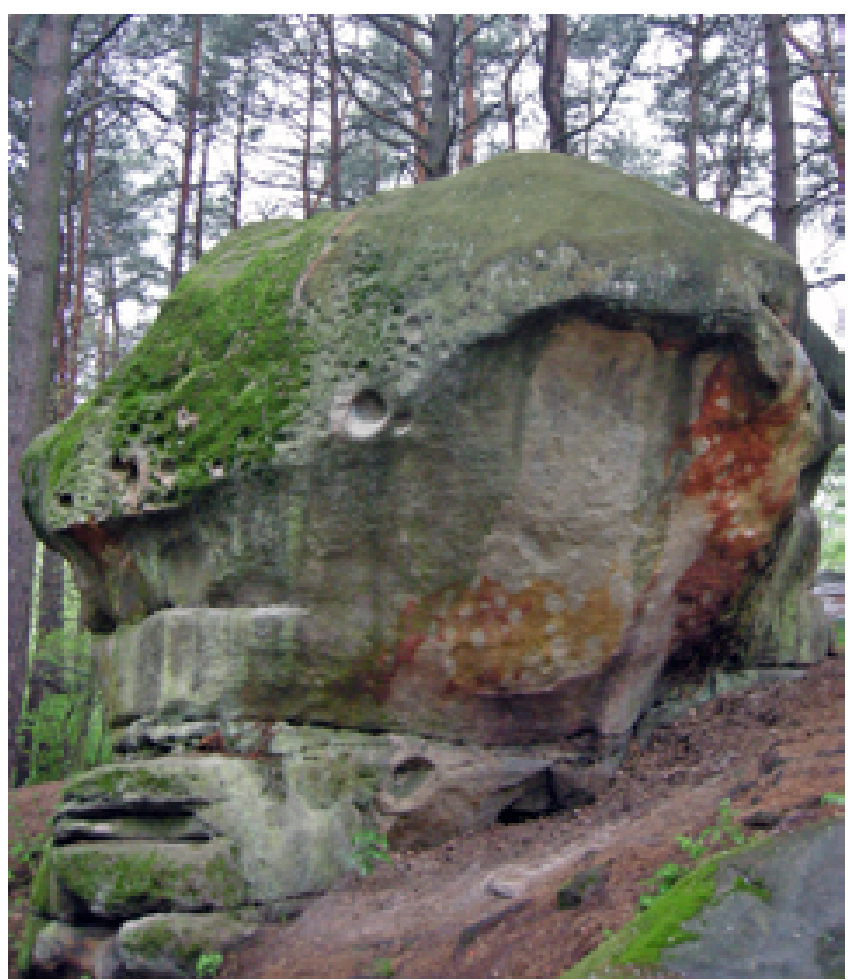

Fig. 2. Isolated mushroom-shaped rocky form in the Stone Town Reserve, photo A. Waśkowska • Grzyb skalny w rezerwacie Skamieniałe Miasto, fot. A. Waśkowska

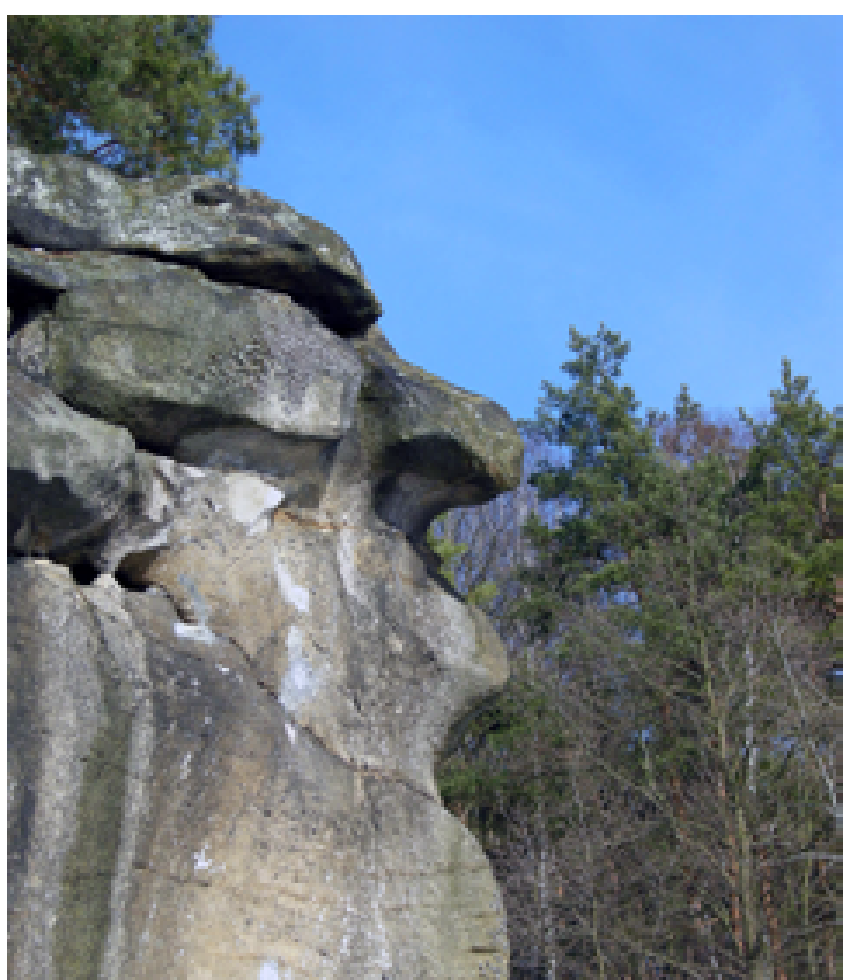

Fig. 3. The Witch (Czarownica) - one of the most famous rocky forms in Ciężkowice, photo A. Waśkowska • Czarownica - jedna z najsłynniejszych form skałkowych w Ciężkowicach, fot. A. Waśkowska 


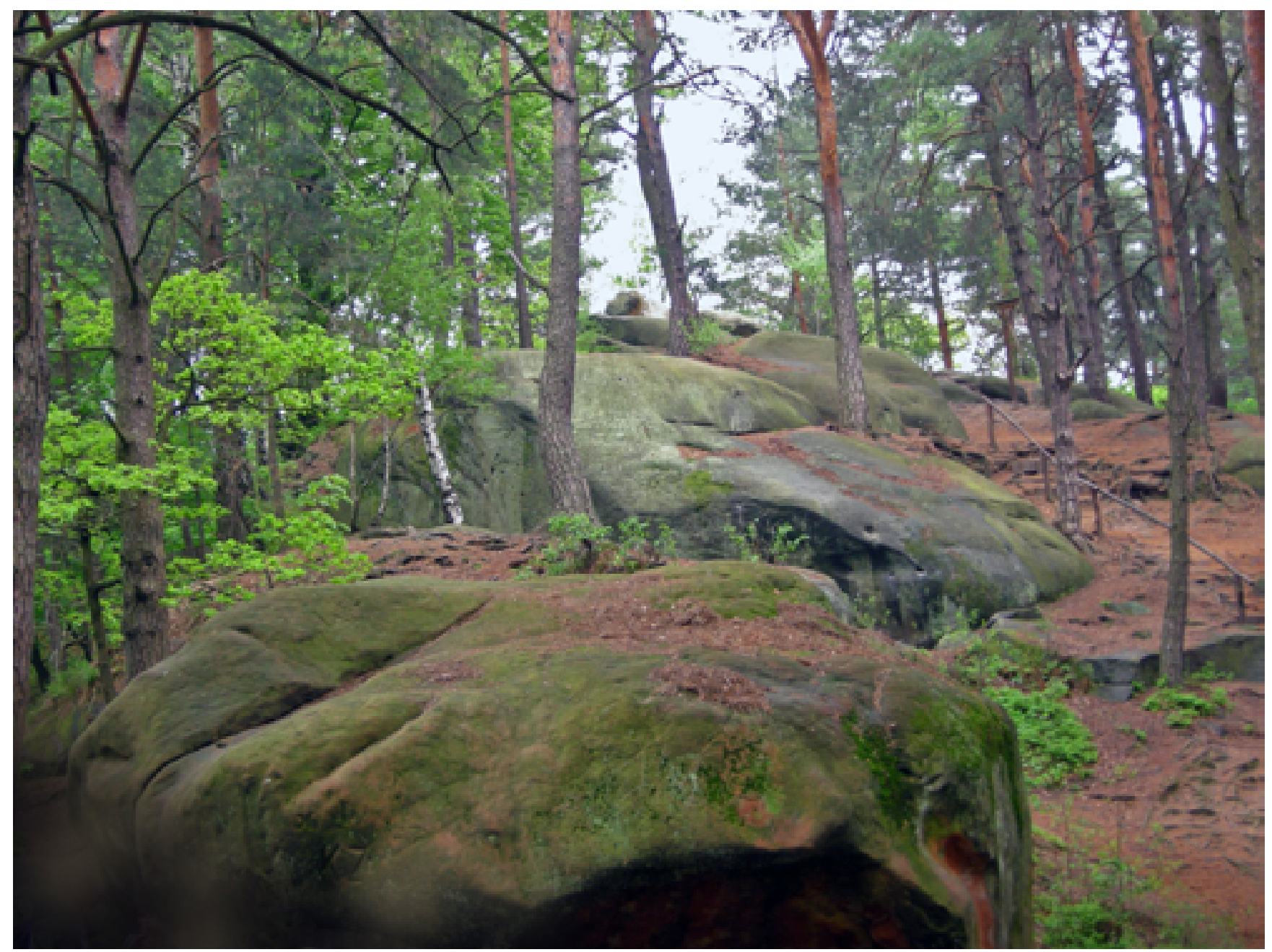

Fig. 4. The rocky forms in Stone Town, photo A. Waśkowska • Formy skałkowe w Skamieniałym Mieście, fot. A. Waśkowska

The majority of the Ciężkowice Sandstone rocky forms are concentrated in the southeastern part of the Park. The largest groups of rocky forms occur in the Ciężkowice area; these are for example 'the Stone Town' (Skamieniałe Miasto) Reserve, the 'Witches' Waterfall' (Wodospad Czarownic) natural monument and the quarry in Ostrusza. Other large objects are rocky forms: 'the Wieprzek Tors' in Siekierczyna, 'the Devils' Playground' (Diable Boisko) in Pławna, and the 'Devil's Rocks' (Diable Skaty) in Bukowiec. Like those previously listed, these are also covered by legal protection (Fig. 1).

\section{Geological structure}

The Ciężkowice-Rożnów Landscape Park is situated within the Outer Carpathians, which consist of several nappes. The study area occurs within the Silesian Nappe. The lithological inventory of this nappe includes deposits formed mainly in the Silesian Basin (e.g. Książkiewicz, 1962, 1977; Unrug, 1979; Cieszkowski et al., 1985; Słomka, 1995; Dziadzio et al., 2005;
Golonka, Waśkowska-Oliwa, 2007; Golonka et al., 2013 and papers cited therein), which was a part of the Carpathian Basin. Sedimentation in the Silesian Basin lasted from the Jurassic until the Oligocene. In the Silesian Nappe lithological $\log$, sequences of deep-water mainly deposits are generally dominated by various types of turbidites (Koszarski, 1956; Leszczyński, 1981, 1989; Dziadzio et al., 2005).

The rocky forms of the Ciężkowice-Rożnów Landscape Park were formed within the Ciężkowice Sandstone, which was deposited during the Early Paleogene (Fig. 5). The Ciężkowice Sandstone is composed mainly of thick-bedded sandstones, conglomeratic sandstones, and conglomerates forming, in the form of thick lenses between packets of variegated shales and thin-bedded shaley-sandstone flysch (e.g. Leszczyński, 1981, 1989; Cieszkowski et al., 1991; Leszczyński, Radomski, 1994). From one to three Ciężkowice Sandstone levels occur within the area of the Park (Cieszkowski et al. 1991; Leszczyński, Radomski, 1994), with rocky forms representing the uppermost level, of Eocene age. Its thickness is estimated at ca. $170 \mathrm{~m}$ (Cieszkowski et al., 1991). 

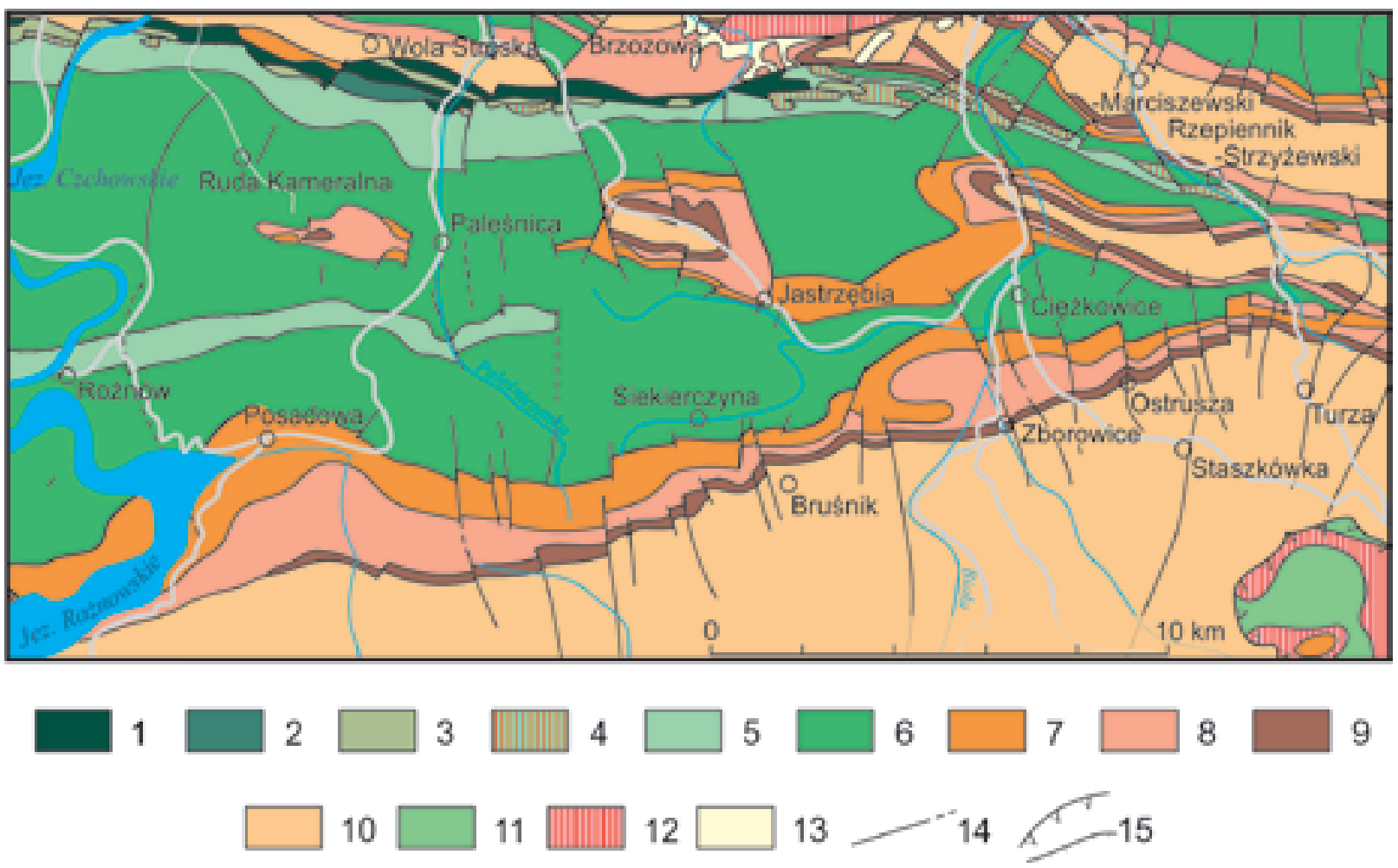

Fig. 5. Geological map of the study area (Burtan et al., 1981; Nescieruk et al., 1992 - modified). Silesian Nappe: 1 - Cieszyn Beds, 2 - Hradiste Beds, 3 - Lgota Beds, 4 - Variegated Shales (Cr), 5 - Godula Beds, 6 - Istebna Beds, 7 - Ciężkowice Beds, 8 - Hieroglyphic Beds, 9 - Menilite Beds, 10 - Krosno Beds. Magura Nappe: 11 - Inoceramian Beds, 12 - Variegated Shales (Pg); 13 - Miocene deposits, 14 - faults, 15 - overthrusts - Mapa geologiczna rejonu badań (mapa za Burtan et al., 1981; Nescieruk et al., 1992 - zmieniona). Płaszczowina śląska: 1 - warstwy cieszyńskie, 2 - warstwy grodziskie, 3 - warstwy lgockie, 4 - łupki pstre (Cr), 5 - warstwy godulskie, 6 - warstwy istebniańskie, 7 - warstwy ciężkowickie, 8 - warstwy hieroglifowe, 9 - warstwy menilitowe, 10 - warstwy krośnieńskie. Płaszczowina magurska: 11 - warstwy inoceramowe, 12 - hupki pstre (Pg); 13 - utwory mioceńskie, 14 - uskoki, 15 - nasunięcia

\section{Sedimentological facies analysis in the interpretations of deposition environments}

The Flysch Carpathians are built of thick packets of clastic rocks. They constitute fine-grained layers (claystones and mudstones) and coarse-grained layers (sandstones and conglomerates), interbedding each other. Other lithological varieties of deposits occur among them. These deposits mostly represent deep-sea sedimentary environments. The analysis of lithological and sedimentary features of deposits in particular sections can contribute to the interpretation of the sedimentary environment of these deposits. It is one of the points in the research methodology called sedimentological facies analysis, which ultimately leads to the development of a spatial model of the sedimentary basin within a given time interval. The analysis of the sedimentary environment itself is based on the observation of a group of features, whose presence or absence determines the interpretation. The flysch environment has been discussed in many publications (e.g. Shanmugam, Moiola, 1988; Einsele, 1992; Reading, Richards, 1994; Galloway, 1998; Stow et al., 1998; Shanmugam, 2000; Stow, Mayall, 2000). The most important features considered are: lithofacies variability, the fraction constituting the sediments, the character of the bottom layers surfaces, lateral extension of layers, sedimentary structures, the occurrence of positive or negative sequences in the sections, and many others.

Leszczyński (1981) conducted regional studies on the sedimentary environment of the Ciężkowice Sandstone. He pointed to the environment of the distributary channels and their levees in the submarine fan, as a depositional environment of these deposits (Fig. 6). The structural and textural features of the Ciężkowice Sandstone are clearly visible on the walls' surface of the rocky forms. Owing to selective weathering, they are exposed on the walls of outcrops and protrude in the surface relief (Figs 2, 3, 7, 8, 9). An essential advantage associated with sedimentological observations of rocky forms is the possibility to follow the course and development of structures in various cross sections of the walls.

\section{Sedimentological analysis of the Ciężkowice Sandstone}

The Ciężkowice Sandstone developed within a submarine fan, in its central part, chiefly in the environment of distributary channels (Leszczyński, 1981) (Fig. 6). This environment is indicated by a set of characteristic features. The deposits are primarily represented by lithofacies of sandstones, conglomeratic sandstones, conglomerates, and sedimentary deformed deposits (Figs 7, 8, 9). 


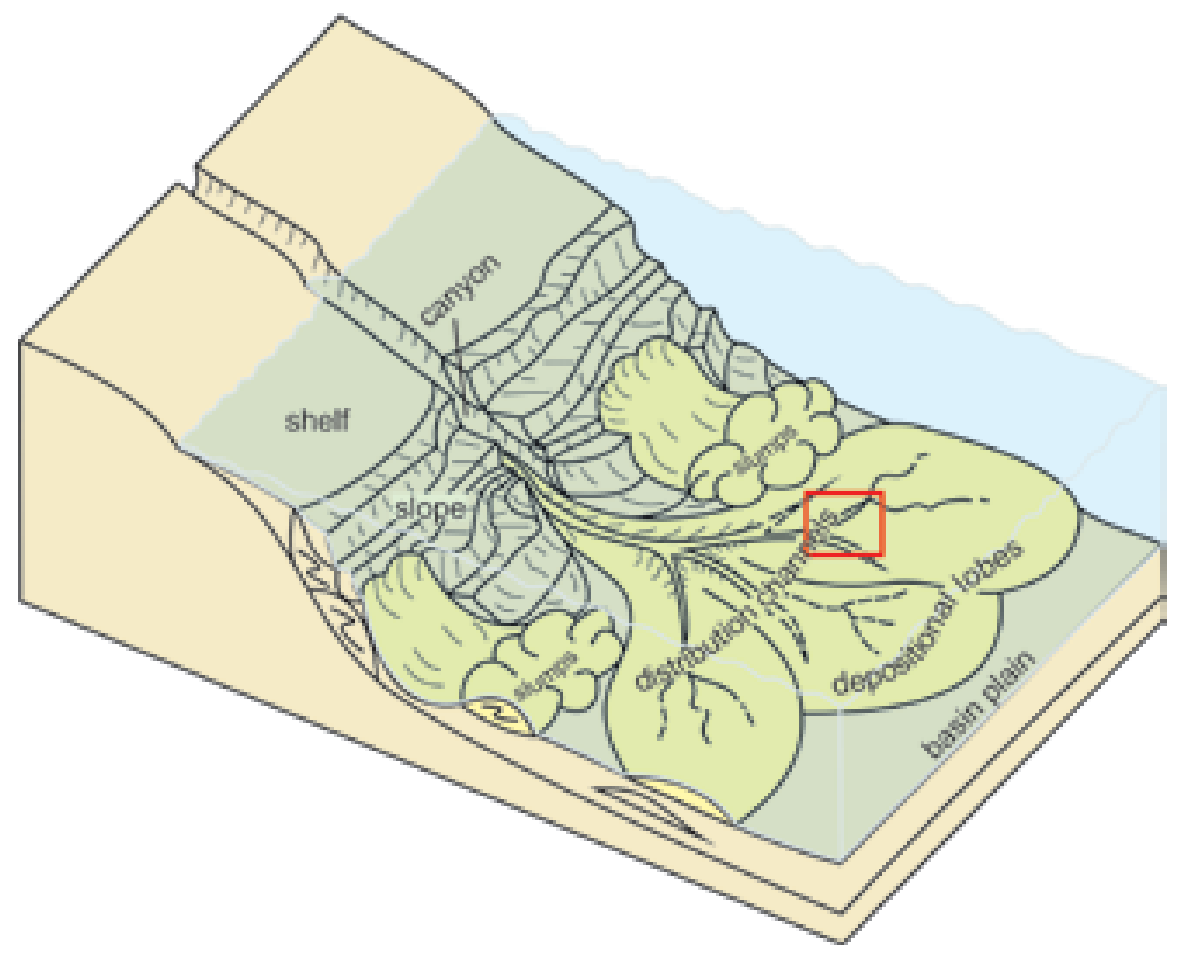

Fig. 6. Model of a submarine fan (see also Reading, Richards, 1994) • Model stożka sedymentacyjnego (por. Reading, Richards, 1994)

A lithofacies of sandstones with intercalated mudstones occurs sporadically (see Ghibaudo, 1992). Such a sequence of lithofacies is typical of deposits developing within this part of the fan. The lithofacies development principally affects the next factor taken into account during the analysis of the sedimentation environment, namely the ratio between coarse-grained sandstones (built from psammite and psephite) compared with fine-grained rocks (built from aleurite and pelitic). This ratio clearly exceeds $90 \%$, which is a minimum value for the sediments of distribution channels (Pickering, 1983; Shanmugam, Moiola, 1988).

Clastic material is concentrated in thick and very thick layers, more rarely - in medium-thick layers (Figs 2, 10, 11). Their bottom surfaces are often uneven and bear an erosional character. On many rocky forms surfaces, erosional channels can be seen, cutting deep into the underlaing beds (Figs 3, 10). Amalgamated beds are also common; whose characteristic feature is disappearing bedding surfaces within a single, thick bed (Figs 7, 8). Such a characteristic results from collateral overlapping of subsequent currents carrying clastic material. On some of the bottom surfaces, deformation structures are marked in the form of load casts (Figs 8, 9). These result from unstable density layering, occurring within two packets of sediments with different viscosities. In the group of rocky forms named 'Badger' (Borsuk) in 'the Stone Town' (Skamieniate Miasto). Reserve extraordinarily interesting structures occur, possibly of similar origin (Fig. 9). They emerged as a result of sediments of different viscosities deposited on the sea floor, where the layer deposited later had higher viscosity and was more plastic than the layer underneath. In effect, the overlaying layer was torn apart, and its isolated fragments fell down within the lower-viscosity layer below. In the course of this movement, the plastic deposits folded and rotated and were then 'frozen' in the underlying bed.

A medium- and coarse psammite fraction (up to $2 \mathrm{~mm}$ in size) dominates in the beds, with a fine- and medium psephite fraction occurring alongside (Figs 7, 8, 9). Among the coarser grains, the ones found most often are those of $0.5-2 \mathrm{~cm}$ size, though larger ones, measuring up to several centimetres, also occur. Less commonly, fine psammite can be observed and, only rarely, an aleurite fraction occurs.

The analysis of the internal form of the beds indicates a characteristic sequence of depositional structures. These consist of normal graded bedding, where the grain size decreases towards the top of the bed (most often starting from psephite grain-size, up to psammite grain-size), horizontal stratifications and laminations, in many cases highlighted by the graded bedding within the laminae, as well as cross-stratification (Figs 7, 8). Streaks are also present, associated with concentrations of coarser material within finer sediment.

In some places, shale clasts and armored clay balls occur (Fig. 8). At present, only their traces are found in the form of vugs. The vugs occurring after shale clasts are elongated, disc-shaped, and many of them contain only remnants of the material that once filled them. The vugs created after armored clay balls are round in their cross-sections, and their internal surfaces bear traces left by psephite grains or the grains themselves, sized up to $1 \mathrm{~cm}$, chiefly made of quartz. The balls are rock fragments, most often of claystone or mudstone, which rolled on the sloping sea bottom and were later deposited together with the remaining clastic material carried by a current. On the other hand, the shale clasts emerged when already lithified deposits were torn and carried away, in fragments by water and, subsequently, deposited. 

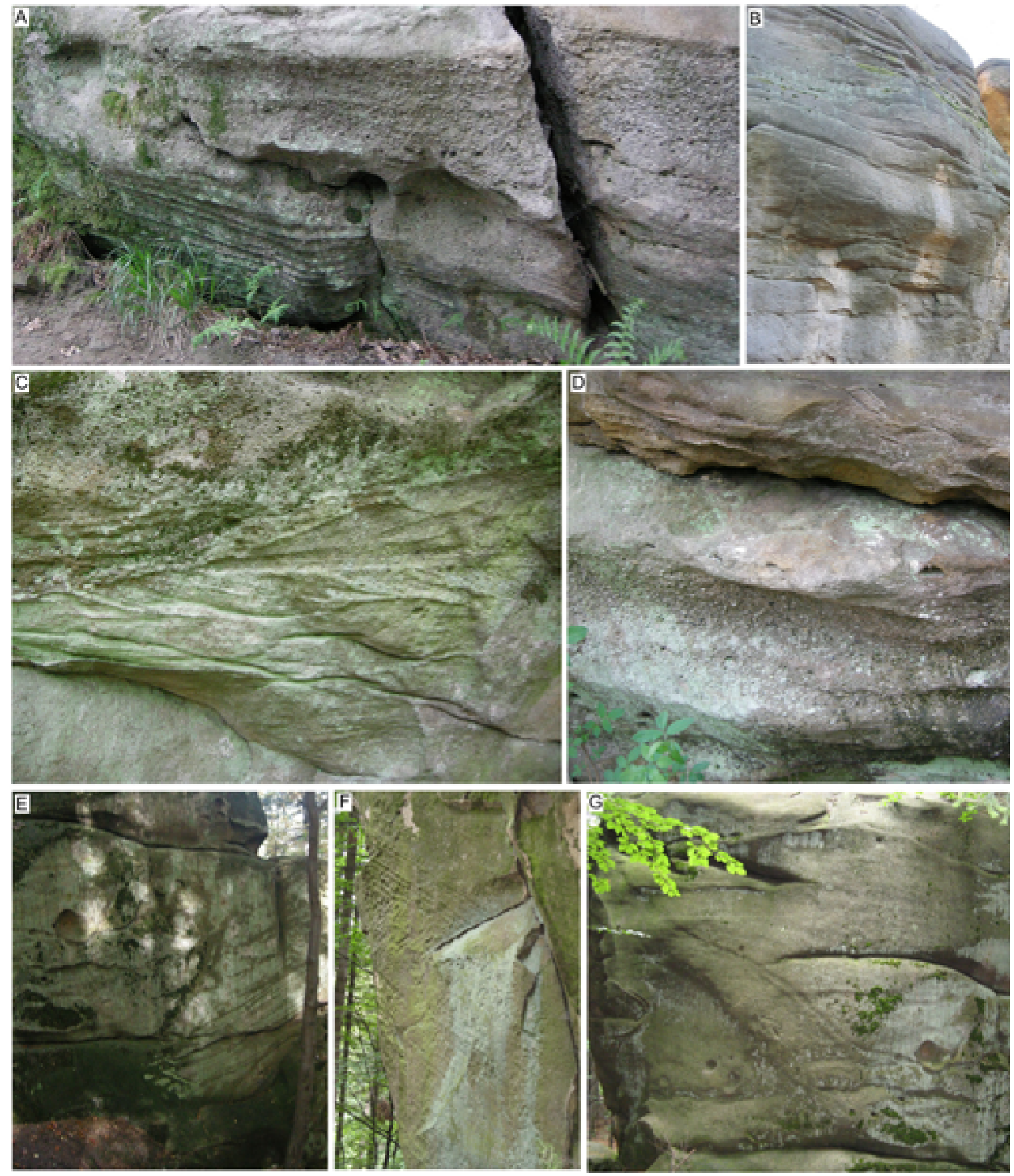

Fig. 7. Selected sedimentary structures and texture exposed in the Ciężkowice-Rożnów Landscape Park, photo A. Waśkowska: A - the lithofacies of parallel-stratified sandstones passing into conglomeratic sandstone lithofacies (rocky form in Stone Town), B - parallel stratification in the sandstone layer within the Wieprzek Tors, C - the cross-stratified sandstone of the Stone Town rocky form, D - the normal graded conglomeratic sandstone (the Wieprzek Tors), E, F - cross-stratified sandstones in the Bukowiec Reserve, G - the amalgamated sandstone bed in the Bukowiec Reserve - Wybrane przykłady struktur sedymentacyjnych i tekstur w Ciężkowicko-Rożnowskim Parku Krajobrazowym, fot. A. Waśkowska: A - litofacja piaskowców warstwowanych równolegle przechodząca w litofację piaskowców zlepieńcowatych (skałka Skamieniałego Miasta), B - równoległe warstwowanie w ławicy piaskowca (skałka Wieprzek), C - warstwowanie przekątne w piaskowcu skałki ze Skamieniałego Miasta, D - uziarnienie frakcjonalne normalne w piaskowcu zlepieńcowatym (skałka Wieprzek), E, F - piaskowce przekątnie warstwowane w rezerwacie Bukowiec, G-ławica amalgamowana piaskowca w rezerwacie Bukowiec 


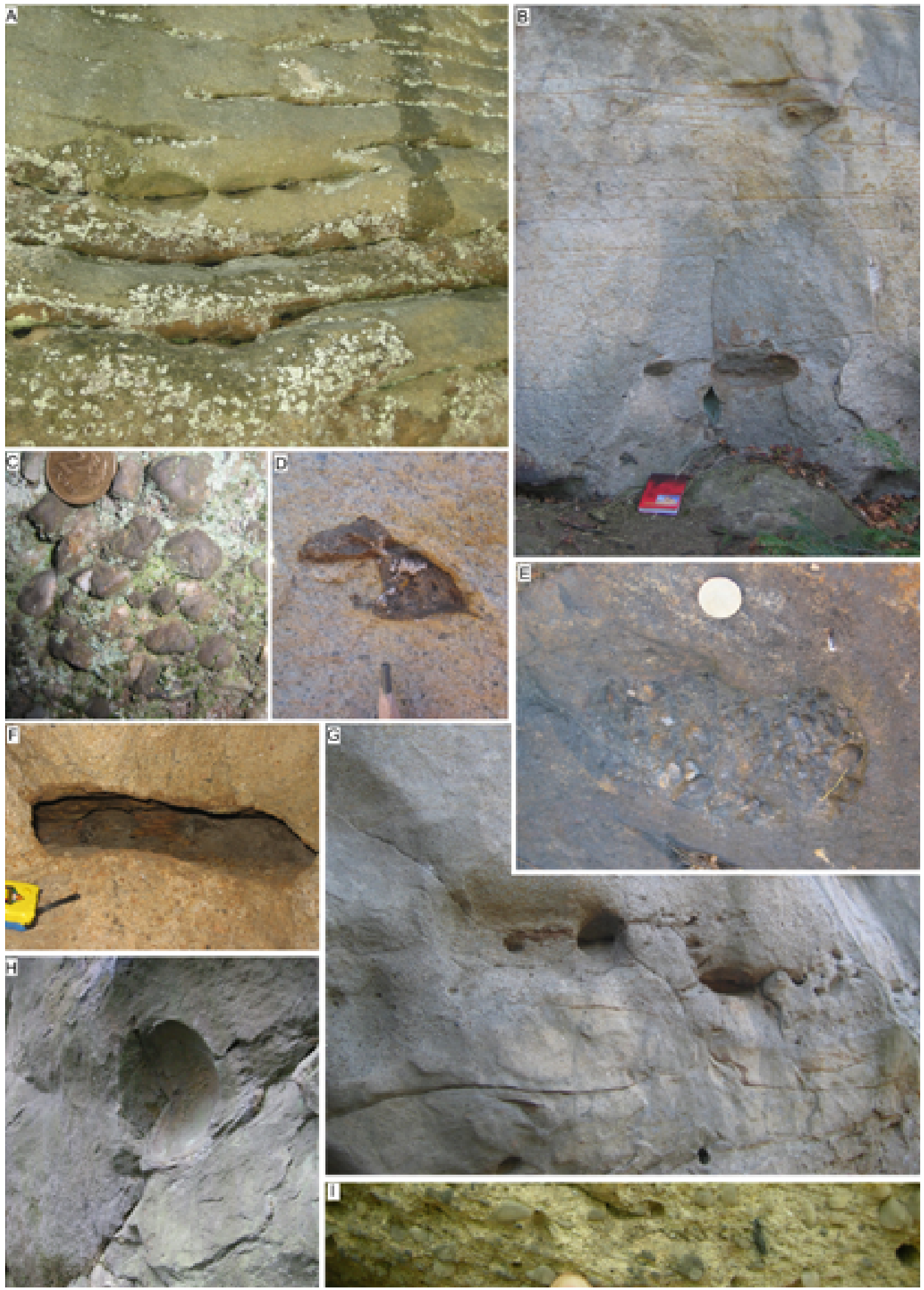

Fig. 8. Selected sedimentary structures and textures exposed in the Ciężkowice-Rożnów Landscape Park, photo A. Waśkowska: A - the amalgamated sandstone bed in Stone Town, B - very-thick, parallel laminated sandstone layer within the Wieprzek Tors, C - conglomerate in a rocky form, Stone Town, D, F - shaly clast in conglomeratic sandstone, forming the Wieprzek Tors, E - trace of an armoured ball left in the sandstone exposed in the Ostrusza quarry, $\mathrm{G}$ - normal gradation in a conglomeratic sandstone (the Wieprzek Tors), $\mathrm{H}-\mathrm{a}$ vug after a rocky ball in the sandstones of the Stone Town rocky form, I - a fraction of psephite and psammite, in the deposits of the Wieprzek Tors. • Wybrane przykłady struktur sedymentacyjnych i tekstur w Ciężkowicko-Rożnowskim Parku Krajobrazowym, fot. A. Waśkowska; A - ławica amalgamowana w Skamieniałym Mieście, B - ławica równolegle laminowana w skałce Wieprzek, C - zlepieńce w skałkach Skamieniałego Miasta, D, F - klasty łupkowe w piaskowcu zlepieńcowatym skałki Wieprzek, E - ślad po toczeńcu uzbrojonym w piaskowcach kamieniołomu Ostrusza, G - uziarnienie frakcjonalne normalne w piaskowcu zlepieńcowatym (skałka Wieprzek), H - ślad po toczeńcu w piaskowcach skałek w Skamieniałym Mieście; I - tekstura psefitowa i psamitowa w utworach piaskowcowych skałki Wieprzek 


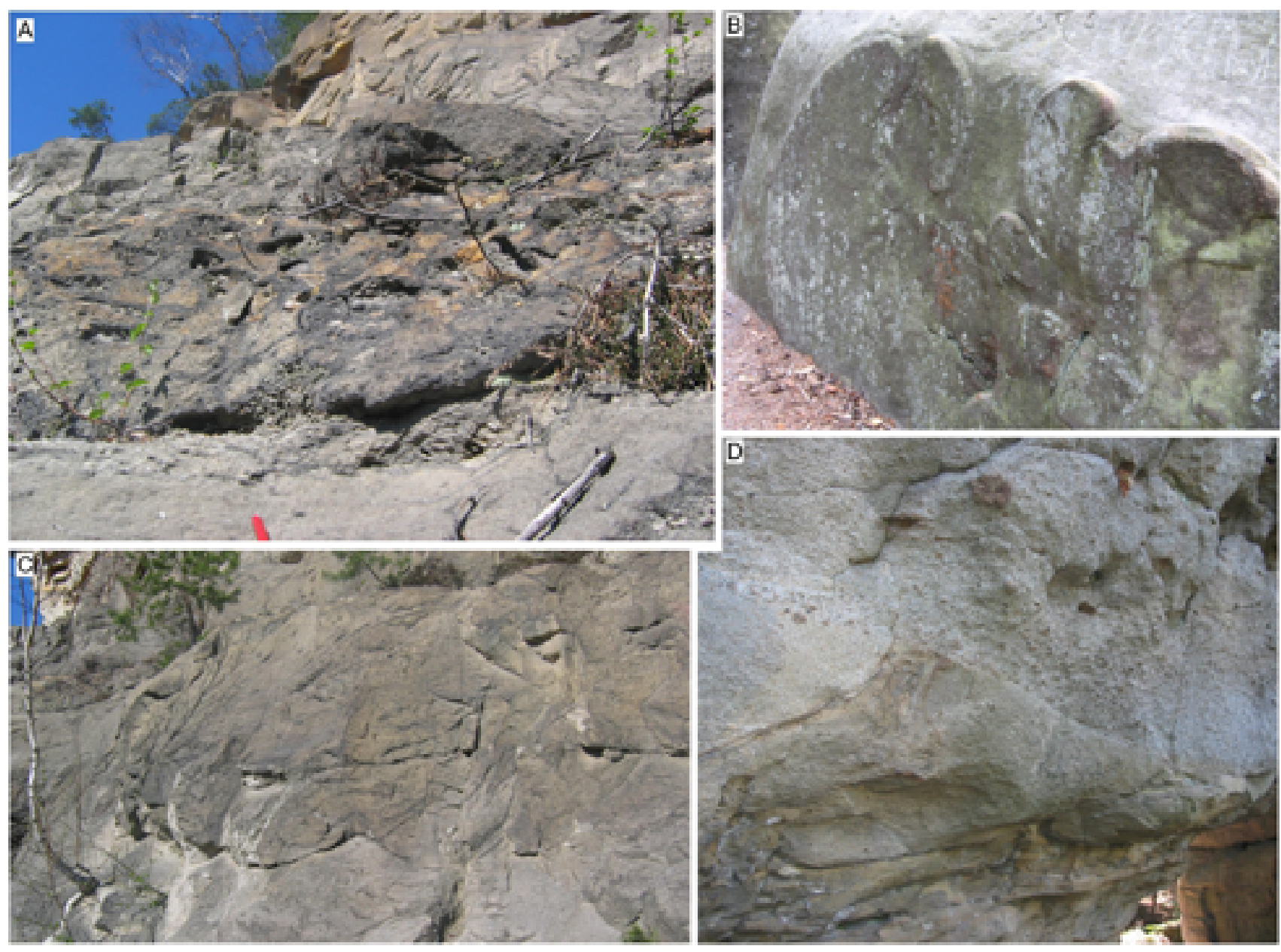

Fig. 9. Examples of deformation structures in the sandstones of the Ciężkowice-Rożnów Landscape Park, photo A. Waśkowska: A - the submarine slump deposits in the Ostrusza quarry section, B - structures of unstable density layering in the sandstones, within the rocky form of the Stone Town, C - the load casts layer in the Ostrusza quarry section, D - the load casts in the sandstones of the Wieprzek Tors - Przykłady struktur deformacyjnych w obrębie skałek Ciężkowicko-Rożnowskiego Parku Krajobrazowego, fot. A. Waśkowska: A - utwory podmorskiego osuwiska w profilu kamieniołomu Ostrusza, B - struktury niestatecznego warstwowania gęstościowegow piaskowcach Skamieniałego Miasta, C - pogrzęźnięta ławica w profilu kamieniołomu Ostrusza, D - pogrązy w piaskowcach skałki Wieprzek

A very crucial feature of these deposits, which determines their classification in the environment of the distribution channels, is the presence of so-called positive sequences (Figs 10, 11). They consist of sets of beds showing the decreasing thickness towards the top, also often coupled with a decrease in the grain size which forms these beds. Because of the sizes of the rocky forms, numerous amalgamation surfaces, deep-cut erosional channels, or far-advanced weathering processes, it is sometimes difficult to notice such sequences on the rocky form. Nevertheless, outcrops can be found where these are easily noticeable.

The aforementioned features of sediments within the rocky forms of the Ciężkowice-Rożnów Landscape Park indicate that a submarine fan, and more specifically - distributary channels, formed the sedimentary environment (see Leszczyński, 1981) (Fig. 6). It is likely, that in the rocky forms themselves, there are no deposits of levees, which usually occur near channel deposits. These deposits have different characteristics. They are chiefly composed of mudstones with sandstones, and mudstones, which obviously translate into the percentage share of deposits, with coarser grain size, within the profile. In this case, the range should fluctuate within $20 \%$ to $60 \%$ (Pickering 1983, 1985; Słomka, 1995). These sediments do not form rocky forms.

\section{Morphology of rocky forms versus structural features of sandstones}

In the Miocene, because of complicated tectonic processes, the deposits of the Silesian Basin were uplifted, folded, and became part of the Carpathian mountain chain. Since then, these deposits have been subjected in terrestrial conditions to various chemical and physical erosional processes, e.g. frost action, ablation, dissolution, insolation, deflation, corrosion, bio-erosion, etc. These tetanized rocks, exposed on the land surface, have undergone selective destruction, and, with the passage of time, their hardest fragments have become isolated rocky forms (see Klimaszewski, 1947; Alexandrowicz, 1970, 2008, 1978). 


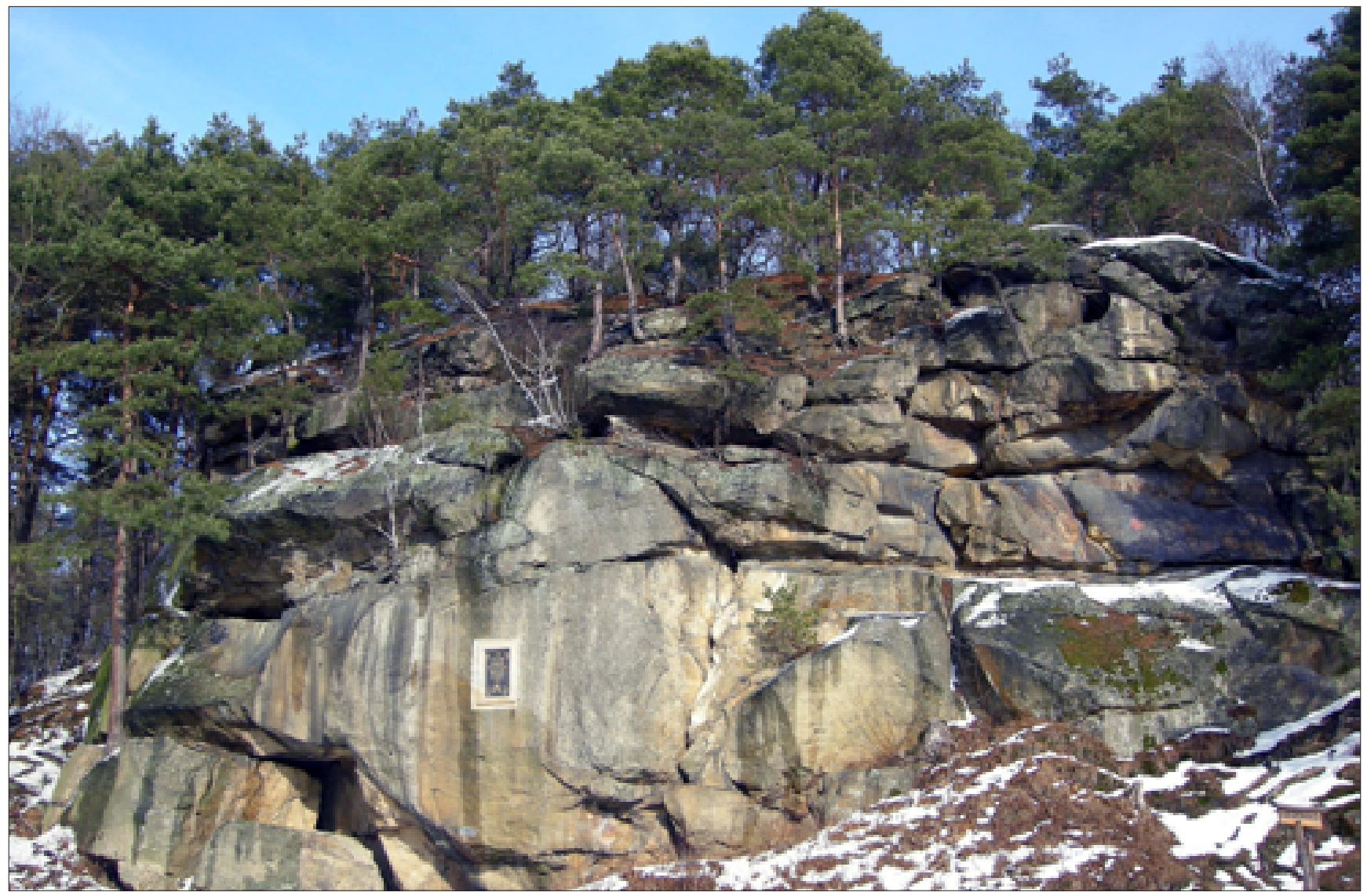

Fig. 10. Positive sedimentary sequences in the deposits of the sandstone of the Grunwald Rock in the Stone Town (phot. A. Waśkowska) • Sekwencja pozytywna w piaskowcach skałki Grunwald w Skamieniałym Mieście, fot. A. Waśkowska

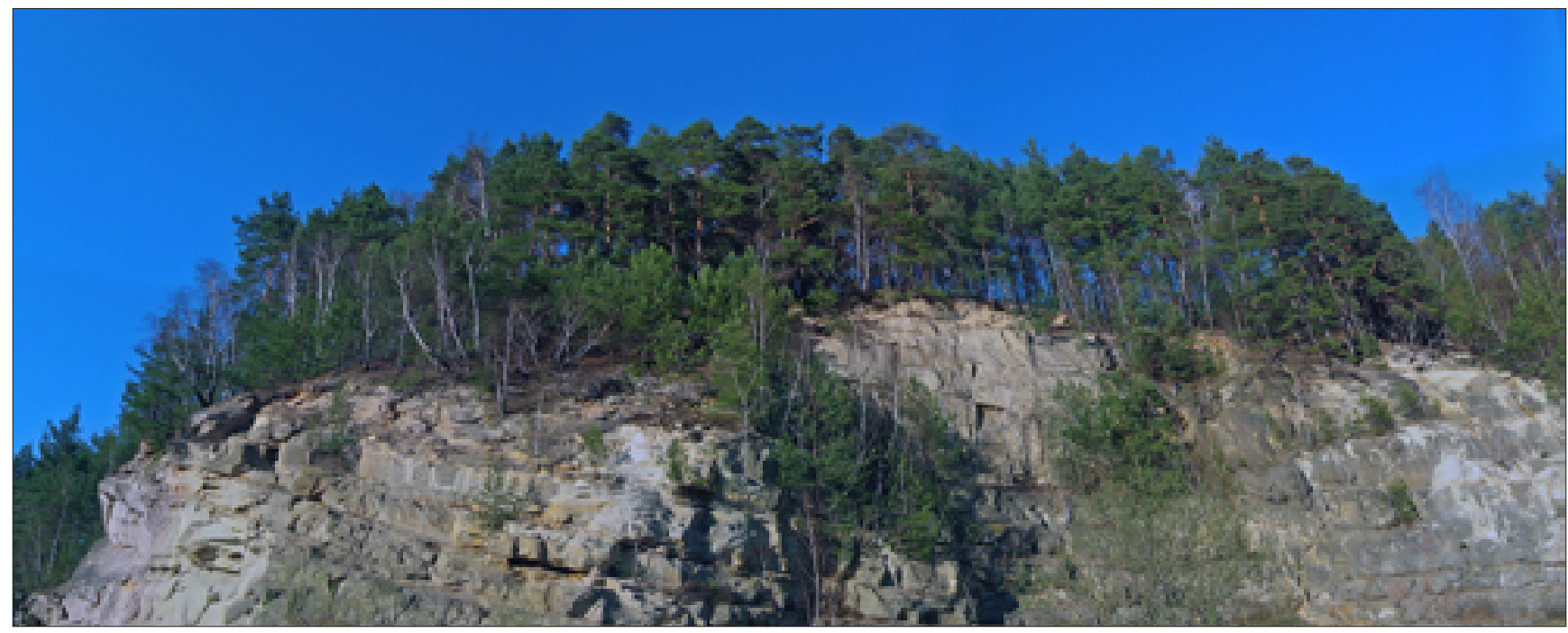

Fig. 11. The Ostrusza Quarry - a monument of inanimate nature, photo A. Waśkowska • Kamieniołom w Ostruszy - pomnik przyrody nieożywionej, fot. A. Waśkowska

The shapes and morphological features of particular rocky forms are, on the one hand, derivatives of quality and intensity of destruction processes, and, on the other hand, the structural features of the rock. The number and types of sedimentary structures are important among the factors determining the morphology of the forms. The different thickness of beds, variable characteristics of graded beddings, numerous amalgamation surfaces, presence of depositional structures, the differences in the mineralogical composition of cement are the factors directly affecting the rocky forms and determining their shapes. Tectonic discontinuities are also important. They all affect the physical parameters of the rock in particular sandstone layers, as well as the individual resistance of these layers to erosion. 

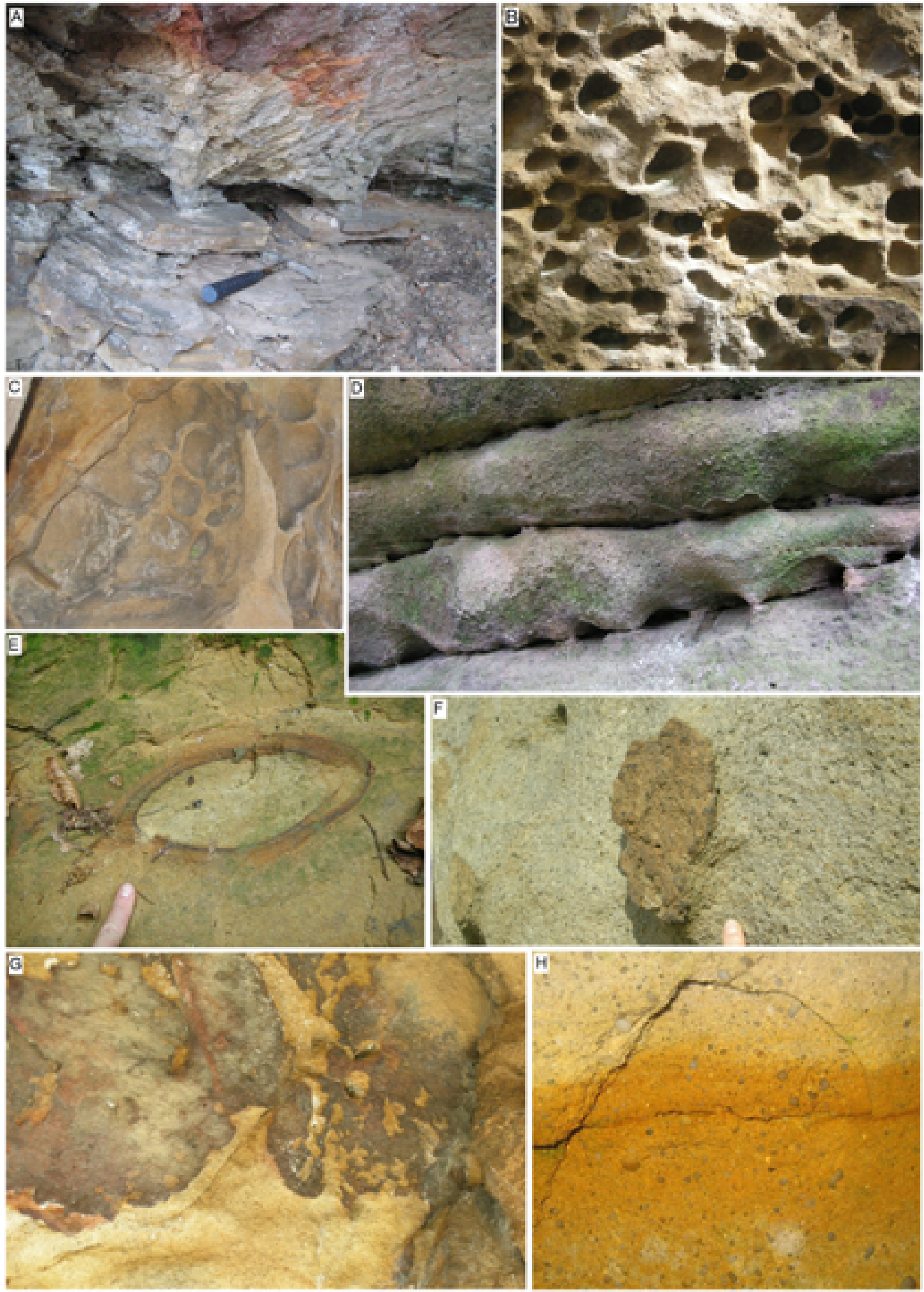

Fig. 12. Typical weathering structures - examples from the Ciężkowice-Rożnów Landscape Park area, photo A. Waśkowska: A - arcade structures in sandstone from the Bukowiec Reserve, B - the cellular structure on the wall surface of a rocky form in Stone Town, C - the honeycomb structure on the rocky wall, Wieprzek Tors, D - the arcade structures developed along the bedding surface in the Stone Town tor - initial forms, E - the diffusive Liezegang rings in sandstone of the Witches'Gully, F - the remnant of limonitic crust on the wall of the Czarownica rock, $\mathrm{G}$ - the limonite cover on the surface of the Czarownica rocky form, $\mathrm{H}$ - the limonitic streak in the clonglomeratic sandstone of the Witches' Gully • Typowe struktury wietrzeniowe - przykłady z obszaru Ciężkowicko-Rożnowskiego Parku Krajobrazowego, fot. A. Waśkowska: A - struktury arkadowe w piaskowcach rezerwatu Bukowiec, B - struktury komórkowe na powierzchni skałki w rezerwacie Skamieniałe Miasto, C - struktura plastra miodu na powierzchni skałki Wieprzek, D - struktury arkadowe rozwinięte wzdłuż powierzchni warstwowania w skałce Skamieniałego Miasta - formy inicjalne, E - pierścienie dyfuzyjne Liezeganga w piaskowcu na terenie Wąwozu Czarownic, F - resztki skorupy limonitycznej na skałce Czarownica, G - polewa limonityczna na powierzchni skałki Czarownica, $\mathrm{H}$ - smugi limonityczne w piaskowcach zlepieńcowatych Wąwozu Czarownic 
Apart from sedimentary structures, weathering structures also appear on the surfaces of rocky forms. The cellular structures, honeycomb structures or arcade ones, occurring in the form of oblong vugs, are among the most commonly found features (Fig. 12). The arrangement of these structures is associated with the lithological development of the deposits. The cellular and honeycomb structures usually occur within massive beds or those with grain gradation, and they are often concentrated under overhanging rocks. Water running on the surfaces of rocky forms has also a major influence on the construction of these structures. Arcade structures are found on the bottom parts of the beds, forming the top interbedding, sealed by fine material.

\section{Discussion}

The sandstone rocky forms in the Ciężkowice-Rożnów Landscape Park are one of the elements that determine the natural attractiveness of the area. They are objects which stir the curiosity of tourists and affect the intensity of tourist traffic in the area. The rocky forms have an interesting morphology and high esthetic value. These forms have been repeatedly described in popular scientific publications, although their lithological and sedimentary characteristics constitute are of secondary importance.

The sandstone rocky forms developed in deep-sea conditions, in the environment of a submarine fan. A great variety of sedimentary structures occurs within them. It is worth emphasizing, that these structures are clearly visible on the walls' surfaces of these rocky forms, as they have been exposed and well-marked in microrelief by the selective action of weathering factors. This is one of the evident advantages of these geotouristic objects. Another advantage of the outcrops found here, is the possibility to follow the structures on various cross-sections of walls of the rocky forms in their lateral continuity. The scale of analytical possibilities is very high, and it markedly exceeds the outcrops in quarries or stream beds. With skillful determination of these diverse features, the spectrum of observations can be more complex, which predisposes the rocky forms from the Ciężkowice Sandstone as highly valuable geotouristic objects.

\section{Summary}

One of the largest concentrations of rocky forms in the Outer Carpathians occurs in the Ciężkowice-Rożnów Landscape Park. They are formed within the solid sandstone complex of Eocene age, belonging to the Ciężkowice Sandstone. The Ciężkowice Sandstone is represented by rocky forms developed in deep-sea conditions, in the environment of distribution channels of a submarine fan. The lithological-sedimentary features of the Ciężkowice Sandstone, visible on the surfaces of rocky walls, are typical of such an environment. The rocky forms are particularly useful for observation and analysis of sedimentary structures, whose presence is highlighted by microrelief on the outcropped rocky surfaces.

\section{Acknowledgments}

This paper was supported by AGH University of Science and Technology in Krakow grant no. 11.11.140.173 and by Micropaleontology Press Europe.

\section{References (Literatura)}

Alexandrowicz Z., 1970. Skałki piaskowcowe w okolicy Ciężkowic nad Białą. Ochrona Przyrody, 35: 281-335.

Alexandrowicz Z., 1977. The origin of sandstone tors in the Polish Western Carpathians. Bulletin de L'Academie Polonaise des Sciences, Serie des Sciences de La Terre, 25: 83-90.

Alexandrowicz Z., 1978. Sandstone tors of the Western Flysch Carpathians. Prace Geologiczne Komisji Nauk Geologicznych Polskiej Akademii Nauk Oddziat w Krakowie, 113: 1-86.

Alexandrowicz Z., 2006. Framework of European geosites in Poland. Nature conservation, 62: 63-87.

Alexandrowicz Z., 2008. Sandstone rocky forms in Polish Carpathians attractive for education and tourism. Przeglad Geologiczny, 58: 680-687.

Alexandrowicz Z., Poprawa D., 2000. Ochrona georóżnorodności w polskich Karpatach. Państwowy Instytut Geologiczny.

Bartuś T., Bębenek S., Doktor M., Golonka J., Ilcewicz-Stefaniuk D., Joniec A., Krąpiec M., Krobicki M., Łodziński M., Margielewski W., Mastej W., Mayer W., Miśkiewicz K., Słomka E., Słomka T., Stadnik R., Stefaniuk M., Strzeboński P., Urban J., Waśkowska A., Welc E., 2012. The catalogue of the geoturist sites in nature reserves and monuments. AGH Akademia Górniczo-Hutnicza.

Burtan J., Golonka J., Oszczypko N., Paul Z., Ślączka A., 1981. Mapa geologiczna Polski 1 : 200 000, arkusz Nowy Sacz, B - mapa bez utworów czwartorzędowych. Wydawnictwa Geologiczne.

Cieszkowski M., Ślączka A., Wdowiarz S., 1985. New data on structure of the flysch Carpathians. Przeglad Geologiczny, 33: 313-333.

Cieszkowski M., Koszarski A., Leszczyński S., Michalik M., Radomski A., Szulc J., 1991. Szczególowa mapa geologiczna Polski 1:50 000, arkusz Ciężkowice. Państwowy Instytut Geologiczny.
Doktor M., Golonka J., Waśkowska A., Słomka T., 2010. The best geotouristic objects of the Silesian Unit, Outer Flysch Carpathians in the vicinity of Krakow, Poland. Scientific Annals, School of Geology, Aristotle University of Thessaloniki, Proceedings of the XIX CBGA Congress, Special Volume, 100: 459-466.

Dziadzio P.S., Enfield M.A., Watkinson M.P., Porębski S.J., 2005. The Ciezkowice Sandstone: Examples of basin-floor fan-stacking patterns from the main (upper Paleocene to Eocene) reservoir in the Polish Carpathians. In: Golonka J., Picha F.J. (eds), The Carpathians and their foreland: Geology and hydrocarbon resources: AAPG Memoir, 84: 477-496.

Einsele G., 1992. Sedimentary basins: evolution, facies, and sediment budget. Springer-Verlag.

Galloway W.E., 1998. Siliciclastic slope and base-of-slope depositional systems: component facies, stratigraphic architecture and classification. American Association of Petroleum Geologists Bulletin, 82, 4: 569-595.

Ghibaudo G., 1992. Subaqueous sediment gravity flow deposits: particular criteria for their description and classification. Sedimentology, 39: 423-454.

Golonka J., Waśkowska-Oliwa A., 2007. Stratigraphy of the Polish Flysch Carpathians between Bielsko-Biała and Nowy Targ (in Polish with English summary). Geologia. Kwartalnik AGH, 33: 5-28.

Golonka J., Ślączka A., Waśkowska A., Krobicki M., Cieszkowski M., 2013. Budowa geologiczna zachodniej części polskich Karpat zewnętrznych. In: Krobicki M., Feldman-Olszewska A., (eds), Gtębokomorska sedymentacja fliszowa - sedymentologiczne aspekty historii basenów karpackich, V Polska Konferencja Sedymentologiczna, Państwowy Instytut Geologiczny - Państwowy Instytut Badawczy: 11-62.

Gruszka I., 2009. Walory i formy ochrony przyrody na pogórzu ciężkowickim. Geologia. Kwartalnik AGH, 35: 77-86. 
Sedimentary indicators of a deep sea environment, in the sandstones of rocky forms...

Grzybowski J., 1921. Ciężkowice Sandstones. Kosmos, 46: 222-226.

Klimaszewski M., 1947. Osobliwości skalne w Beskidach Zachodnich. Wierchy, 17: 57-71.

Kondracki J., 2009. Geografia regionalna Polski. Wydawnictwo Naukowe PWN, Warszawa.

Koszarski L., 1956. Observations on the Ciężkowice Sandstone near Ciężkowice (Carpathian Flysch). Bulletin de L'Academie Polonaise des Sciences Cl., 3, 4, 6: 393-398.

Książkiewicz M., 1962. Atlas geologiczny Polski. Zagadnienia stratygraficzno-facjalne. Kreda i starszy trzeciorzed polskich Karpatach zewnętrznych. Wydawnictwa Geologiczne, Warszawa.

Książkiewicz M., 1977. The tectonics of the Carpathians. In: Pożaryski W. (ed.), Geology of Poland, Volume IV, Tectonics. Wydawnictwa Geologiczne, Warszawa, 476-620.

Leszczyński S., 1981. Piaskowce ciężkowickie jednostki śląskiej w polskich Karpatach: studium sedymentacji głębokowodnej osadów gruboklastycznych. Annales Socetatis Geologorum Poloniae, 51: 435-502.

Leszczyński S., 1989. Characteristics and origin of fluxoturbidites from the Carpathians Flysch Cretaceous - Paleogene, South Poland. Annales Socetatis Geologorum Poloniae, 59: 435-502.

Leszczyński S., Radomski A., 1994. Objaśnienia do szczegółowej mapy geologicznej Polski w skali 1: 50 000, arkusz Ciężkowice. Wydawnictwa Geologiczne, Warszawa.

Motyka J., 1927. Skamieniałe Miasto. O skałkach ciężkowickich i ich ochronie. Ziemia, 12: 100-104.

Nescieruk P., Paul Z., Ryłko W., Szymakowska F., Wójcik A., Żytko K., 1995. Mapa geologiczna Polski 1:200 000, arkusz Jasło, B-mapa bez utworów czwartorzędowych. Wydawnictwo Kartograficzne Polskiej Agencji Ekologicznej S.A., Warszawa.
Pickering K.T., 1983. Transitional submarine fan deposits from the late Pre-cambrian Kongsfiord Formation submarine fan, NE Finnmark, N. Norway. Sedimentology, 30: 181-199.

Pickering K.T., 1985. Kongsfjord turbidite system, Norway. In: Bouma A.H., Normark W.R., Barnes N.E. (eds), Submarine fans and related turbidite systems, Springer-Verlag, New York, 237-244.

Reading H.G., Richards M., 1994. Turbidite system in deep-water basin margins classified by grain size and feeder system. American Association of Petroleum Geologists Bulletin, 78: 792-822.

Shanmugam G., 2000. 50 years of the turbidite paradigm (1950s - 1990s): deep-water processes and facies models - a critical perspective. Marine and Petroleum Geology, 17: 285-342.

Shanmugam G., Moiola R.J., 1988. Submarine fans: characteristics, models, classifications and reservoir potential, Earth-Science Reviews, 24: 383-428.

Słomka T., 1995. Głębokomorska sedymentacja silikoklastyczna warstw godulskich Karpat (in Polish with English summary). Prace Geologiczne Polskiej Akademii Nauk, 139: 1-132.

Stow D.A.V., Mayall M., 2000. Deep-water sedimentary systems: new models for the $21^{\text {st }}$ century. Marine and Petroleum Geology, 17: 125-135.

Stow D.A.V., Reading H.G., Collinson J.D., 1998. Deep seas. In: Reading H.G. (ed.), Sedimentary environments: processes, facies and stratigraphy. Blackwell Science, Oxford: 395-453.

Tomek W., 1949. Skamieniałe Miasto w Ciężkowicach koło Tarnowa. Chrońmy Przyrodę Ojczysta, 5: 35-40.

Unrug R., 1979. Palinspastic reconstruction of the Carpathian before the Neogene tectogenesis. Rocznik Polskiego Towarzystwa Geologicznego, 49: 3-21.

Walter H., Dunikowski E., 1883. Geologiczna budowa naftonośnego obszaru zachodniogalicyjskiego Karpat. Część II. Kosmos, 8: 309-334. 